\title{
Tobacco-specific $N$-Nitrosamines [TSNA] in Green Mature and Processed Tobacco Leaves from India*
} by

\author{
S. Y. Bbide, J. Nair, G. B. Maru and U. J. Nair \\ Carcinogenesis Division, Cancer Research Institute, Tata Memorial Centre, Bombay (Parel), India
}

B. V. Kameshwar Rao

Department of Biochemistry, Central Tobacco Research Institute, Rajabmundry, India

\section{K. Chakraborty}

Department of Biochemistry (Tobacco Project), Gujarat Agricultural University, Anand, India

and

\section{K. D. Brunnemann}

Naylor Dana Institute for Disease Prevention, American Healtb Foundation, Valhalla, N.Y., U.S.A.

\section{SUMMARY}

Tobacco-specific $N$-nitrosamines [TSNA] and tobacco alkaloids were determined in green mature tobacco leaves, sun-dried leaves and processed tobacco from the species $N$. rustica and $N$. tabacum cultivated in two different locations. Analyses showed the presence of TSNA in green mature tobacco leaves and the levels of TSNA increased further upon sun-drying and processing. $N$. rustica showed relatively higher amounts of nornicotine as well as of $N^{2}$-nitrosonornicotine [NNN]. A clear correlation between the amount of nicotine and nornicotine and the use of fertilizers was not found.

\section{ZUSAMMENFASSUNG}

Bei zwei jeweils auf zwei verschiedenen Böden gezogenen Tabakarten, $N$. rustica und N. tabackm, wurde untersucht, in welchem $\mathrm{Maße}$ das Blattgut im reifen grünen Zustand, nach Sonnentrocknung und nach weiterer

\footnotetext{
* Received: 4th September 1985 - zccepted: 3rd December 1986.
}

Verarbeitung tabakspezifische $N$-Nitrosamine [TSNA] und Alkaloide enthält. Die Analyseergebnisse zeigen, daß die Nitrosamine im reifen grünen Blatt enthalten sind und im Laufe der Sonnentrocknung und der darauffolgenden Verarbeitung quantitativ zunehmen. $N$. rustica enthielt vergleichsweise größere Mengen an Nornicotin und $N^{\prime}$-Nitrosonornicotin [NNN]. Es gab keine eindeutige Korrelation zwischen dem Gehalt des Tabaks an Nicotin und Nornicotin und der Düngung.

\section{RESUME}

Pour deux variétés de tabac, $N$. rustica et $N$. tabacum, cultivées en deux lieux différents, on a dosé les alcaloīdes et $N$-nitrosamines spécifiques du tabac [TSNA] contenus dans les feuilles vertes à maturité, après séchage au soleil ainsi qu'après traitement ultérieur. Les résultats de cette analyse montrent que les feuilles vertes à maturité contiennent des $N$-nitrosamines dont $\mathrm{la}$ quantité s'accroît pendant le séchage au soleil et au cours du traitement ultérieur. Comparativement, le $N$. rustica contient des quantités plus élevées de nornico- 
tine et de $N^{\prime}$-nitrosonornicotine [NNN]. Il n'a pas été possible d'établir de corrélation nette entre la teneur du tabac en nicotine et nornicotine d'une part, et l'utilisation d'engrais d'autre part.

\section{INTRODUCTION}

Tobacco-specific $N$-nitrosamines [TSNA] have been identified and analyzed in tobacco smoke and in cigarettes from Japan and Western countries (1-3); some data are also available on tobacco used for chewing $(4,5)$. Hoppmann and Adams $(6)$ have shown the presence of TSNA in snuff. BHIDE et al. (7) have detected $N^{\prime}$-nitrosonornicotine [NNN] and several volatile nitrosamines in the "Pandharpuri" variety of chewing tobacco. Since tobacco chewing is a very popular habit among Indian people, it seemed important to study the TSNA in two species of tobacco: $N$. rustica, mainly used for chewing, and $N$. tabacum, used for chewing as well as for smoking.

To study whether TSNA are present in green mature tobacco leaves or whether they are formed during processing/curing, two tobacco species ( $N$. rustica and $N$. tabacum), grown in different places (differing climatically, geographically and in soil type), were analyzed at different stages, namely (a) mature green leaves on the plant, (b) sun-dried leaves harvested from the plant and (c) the processed tobacco ready for sale. For sun-drying, the picked leaves were spread out in the field for a few days. Processing included preparation of bundles of $20-25$ sun-dried leaves stacked together, on which $\sim 100 \mathrm{ml}$ water was sprinkled to keep them moist. These bundles were then kept in the shade for $2-3$ weeks at $30-35^{\circ} \mathrm{C}$ after which the leaves were crushed to coarse granules (this tobacco is then sold loose or in packets for chewing). The present communication reports our findings from these studies.

\section{MATERIALS AND METHODS}

\section{Tobacco Samples}

Tobacco leaves (N. rustica and N. tabacum) were collected from the Central Tobacco Research Institute, Rajahmundry, on the south-eastern coast of India, during March to May of 1984 and from the Tobacco Research Station of the Gujarat Agricultural University, Anand, in the western region of India, from March to May of 1983 and 1984. N. tabacum was studied at all the three stages, whilst $N$. rustica was studied only at the green and sun-dried stages since the sample of processed $N$. rustica was not available.

For every set of green, sun-dried and processed samples, material was derived from a single plant. About 20-25 leaves were obtained from each plant. The required material for green and sun-dried samples was obtained from $3-5$ leaves and the rest were processed conventionally. The green samples were processed immediately after plucking.

\section{Determination of TSNA and Tobacco Alkaloids}

Tobacco material $(10-50 \mathrm{~g})$ was used either for the detection of TSNA or for alkaloid estimation. All reagents and solvents were of analytical grade (E. Merck (Ind.), Bombay, and Bombay Drug House). The method of Cundire and Markunas (8) was used to estimate nicotine and the minor alkaloids with a secondary amino group (e.g. nornicotine, anabasine and anatabine). For TSNA analyses, tobacco material (green $50 \mathrm{~g}$; sun-dried $25 \mathrm{~g}$; processed $10 \mathrm{~g}$ ) was homogenized in citrate phosphate buffer $(10 \mathrm{ml} / \mathrm{g}, \mathrm{pH} 4.5)$ containing $20 \mathrm{~mm}$ ascorbic acid. The homogenate was stirred overnight at room temperature, filtered, and the residue rewashed with $10-50 \mathrm{ml}$ of buffer. The combined filtrates were adjusted to $\mathrm{pH} 5$ with $10 \mathrm{~N} \mathrm{NaOH}$ and extracted with 3 portions $(250 \mathrm{ml})$ of freshly distilled dichloromethane. The organic layer was dried with anhydrous sodium sulfate, concentrated to $5 \mathrm{ml}$ at $50^{\circ} \mathrm{C}$ with a Vigreaux column, and finally concentrated to $1 \mathrm{ml}$ with nitrogen. The concentrated extract was then chromatographed on a basic alumina column $(65 \mathrm{~g}$ packed in n-pentane; degree of activity II; $100 \mathrm{mesh}$; Sarabhai Chemicals, Baroda, India). The column was washed with $n$-pentane $(120 \mathrm{ml})$, the TSNA eluted with distilled dichloromethane $(150 \mathrm{ml})$, and this eluate concentrated to 0.2 to $0.5 \mathrm{ml}$ with a Kuderna-Danish evaporator. The samples were then packed in $1.0 \mathrm{ml}$ screw cap vials and mailed to the Naylor Dana Institute, American Health Foundation, Valhalla, N.Y., U.S.A., for GC-TEA analysis of TSNA (9), namely $N$ '-nitrosonornicotine [NNN], 4-(methylnitrosamino)-1-(3-pyridyl)-1-butanone [NNK], $N$ 'nitrosoanatabine [NAT'] and $N$ '-nitrosoanabasine [NAB].

Sun-dried and processed samples were extracted within one week of being obtained. TSNA are quite stable in dichloromethane. The extraction procedure used prevents formation of nitrosamines during treatment.

\section{RESULTS AND DISCUSSION}

Table 1 shows data on the levels of TSNA in green mature leaves of $N$. tabacum and $N$. rustica collected from Anand (1983 and 1984) and Rajahmundry (1984). It is evident that both species $N$. tabackm and $N$. rustica contain NNN and NNK. $N^{\prime}$-nitrosoanabasine [NAB] could not be detected in $N$. tabacum from either place. The combined values of NAT and NAB in $N$. rustica were high (either separated clearly or obtained as a combined peak). Clear separation of NAT and NAB was not achieved in every sample due to the fact that these analyses were carried out at different time points and column conditions may have varied (9). 
Table 1.

Tobacco-specific N-nitrosamines [TSNA] In mature green leaves of $N$. tabacum and $N$. rustica grown in two locations and in two consecutive years.

\begin{tabular}{|c|c|c|c|c|c|c|c|}
\hline \multirow{2}{*}{ Place } & \multirow{2}{*}{ Year } & \multirow{2}{*}{ Species } & \multicolumn{5}{|c|}{ TSNA ( $\mu g / \mathrm{kg}$ dry weight of tobacco) } \\
\hline & & & NNN & NAT & NAB & $N A T+N A B$ & NNK \\
\hline Anand & 1983 & N. tabacum & 8.2 & n.d. & n.d. & & 0.67 \\
\hline Anand & 1984 & N. tabacum & 35.4 & 61.5 & n.d. & & 11.5 \\
\hline Rajahmundry & 1984 & N. tabacum & 14.0 & 4.6 & n.d. & & n.d. \\
\hline Anand & 1983 & N. rustica & 46100 & 23700 & 5200 & & 2340 \\
\hline Anand & 1984 & N. rustica & 5730 & & & 25900 & 352 \\
\hline Rajahmundry & 1984 & N. rustica & 309 & & & 3360 & 68 \\
\hline
\end{tabular}

n.d.: not detected.

Hecht et al. (10) did not detect NNN and other TṢNA in freshly harvested tobacco, but ANDERson et al. (11) detected NNN in freshly homogenized leaf-cured tobacco.

In the present studies, we have observed a difference in the content of NNN and NNK in the leaves of the same species collected in two consecutive years as well as in those collected from different sites in the same year. It is not known if these differences are due to different climatic conditions or due to the variations in agricultural practices, such as the amounts of fertilizer used, spacing of plants or merely differences in different batches.

The most interesting observation is that there is a several-fold higher amount of NNN in N. rustica, a popular variety used for chewing, when compared to that found in $N$. tabacum. This difference is possibly due to the difference in the nornicotine content of the two species. To investigate this, the levels of nicotine and nornicotine in the cured leaves of the two species grown in 1984 at Anand and Rajahmundry were determined. Simultaneously, information on the quantities of fertilizer used for each species in the two locations was also collected.

Table 2 shows that $N$. rustica leaves from Anand $(200 \mathrm{~kg}$ of fertilizer/ha) had three times as much nornicotine as did $N$. tabacum leaves, whereas the nicotine level of $N$. tabacum was twice that in $N$. rustica. At

Table 2.

Nicotine and nornicotine content $(\%)$ of tobacco leaves in $N$. rustica and $N$. tabacum grown in 1984 at Anand and Rajahmundry with different amounts of fertilizer.

\begin{tabular}{l|l|c|c|c}
\hline \multirow{2}{*}{ Place } & \multirow{2}{*}{ Species } & \multirow{2}{*}{$\begin{array}{c}\text { Fertilizers } \\
(\mathrm{kg} / \mathrm{ha})\end{array}$} & \multicolumn{2}{|c}{ Alkaloids (\%) } \\
\cline { 4 - 5 } & & Nicotine & Nornicotine \\
\hline Rajahmundry & N. tabacum & 20 & 1.7 & 0.06 \\
Rajahmundry & N. rustica & 50 & 5.83 & 0.51 \\
Anand & N. tabacum & 200 & 7.6 & 0.29 \\
Anand & N. rustica & 200 & 3.6 & 0.89 \\
\hline
\end{tabular}

Rajahmundry the amount of fertilizer used was different for the two species, hence precise comparison is not possible. It is observed that nornicotine in $N$. rustica was about 9 times that in $N$. tabacum for a fertilizer ratio of 2:5. But unlike the Anand case, the nicotine level in $N$. rustica was higher than that in $N$. tabacum. It is thus possible that nornicotine is not the only source for NNN formation in $N$. rustica and nicotine may also contribute to the NNN formation. In the literature, reports are available in this respect. НвCHT et al. (13), using ${ }^{14} \mathrm{C}$-labelled nicotine and nornicotine, concluded that in vitro conversion of nicotine and nornicotine to NNN was of similar magnitude, whilst ANDERSON and KASPERBAUER (12) have reported that in tobacco plants which differed genetically in nornicotine content, the NNN levels correlated with their nornicotine levels in tobacco leaves.

Next, we studied the TSNA in tobacco leaves ( $N$. rustica and $N$. tabackm) from Anand in 1984 at the three stages, i.e. mature green, sun-dried and processed tobacco. It is clear from Table 3 that $N$. rustica and $N$. tabacum leaves show a remarkable increase in TSNA, e.g. NNN and NNK, on sun-drying. The combined value of NAT and NAB increased substantially in $N$. rustica on sun-drying; $N$. tabacum also shows a further increase on processing. In the case of $N$. rustica, a processed sample from the same plant was not available for analysis.

Table 3.

Tobacco-speciflc N-nitrosamines ( $\mu \mathrm{g} / \mathrm{kg} \mathrm{dry}$ welght of tobacco) at different stages of the specles $N$. tabecum and N. rustica cultivated at Anand in 1884.

\begin{tabular}{l|c|c|c|c}
\hline Species & Group & NNN & NAT+NAB & NNK \\
\hline N. tabacum & green & 35.4 & 61.5 & 11.5 \\
& sun-dried & 48.9 & 17.0 & 37.0 \\
& processed & 1490 & 1030 & 522 \\
N. rustica & green & 5730 & 25900 & 352 \\
& sun-dried & 15000 & 78200 & 25800 \\
\hline
\end{tabular}


Hzcht et al. have reported that, though they did not detect NNN in green leaves (10), it was detected in tobacco leaves cured under in vitro conditions simulating the curing processes used in the tobacco industry (13). ANDERson and Kasperbauer (12) observed an increase in NNN content of Burley tobacco with processing. The fact that NNN and NNK levels significantly increase during processing shows that the processing of chewing tobacco should be modified to prevent a further increase in TSNA levels. Our present studies, though limited and preliminary in nature, call for detailed studies on tobacco samples (from different areas of cultivation) at different stages and also obtained in different years.

\section{REFERENCES}

1. Hoffmann, D., C. B. Chen and S. S. Hecht: The role of volatile and nonvolatile $N$-nitrosamines in tobacco carcinogenesis; in: A safe cigarette?, edited by G. B. Gori and F. G. Bock, Banbury Rep. 3, Cold Spring Harbor Laboratory Publ., Cold Spring Harbor, N.Y., 1980, pp. 113-127.

2. Hoffmann, D., J. D. Adams, K. D. Brunnemann and S. S. Hecht: Assessment of tobacco-specific $N$ nitrosamines in tobacco products; Cancer Res. 39 (1979) 2505-2509.

3. Bharadwaj, V. P., S. Takayama, T. Yamada and A. Tanimura: $\quad N^{\prime}$-nitrosonornicotine in Japanese tobacco products; Gann 66 (1975) 585-586.

4. Hoffmann, D., K. D. Brunnemann, J. D. Adams and S. S. Hecht: Formation and analysis of $\mathrm{N}$ nitrosamines in tobacco products and their endogenous formation in consumers; in: $N$-nitroso compounds - Occurrence, biological effects and relevance to human cancer, edited by $I$. K. O'Neill, R. C. von Borstel, C. T. Miller, J. Long and H. Bartsch, International Agency for Research on Cancer, Lyon, IARC Sci. Publ. No. 57, 1984, pp. 743-762.

5. International Agency for Research on Cancer, Lyon: Tobacco habits other than smoking, betelquid and areca-nut chewing, and some related nitrosamines; in: IARC monographs on the evaluation of the carcinogenic risk of chemicals to humans, Vol. 37, 1985, 291 pp.

6. Hoffmann, D., and J. D. Adams: Carcinogenic tobacco-specific $N$-nitrosamines in snuff and in the saliva of snuff dippers; Cancer Res. 41 (1981) 4305-4308.

7. Bhide, S. V., A. I. Pratap, N. M. Shivapurkar, A. T. Sipahimalani and M. S. Chadha: Detection of nitrosamines in a commonly used chewing tobacco; Food Cosmet. Toxicol. 19 (1981) 481-483.

8. Cundiff, R. H., and P. C. Markunas: Determination of nicotine, nornicotine and total alkaloids in tobacco; Anal. Chem. 27 (1955) 1650-1653.
9. Adams, J. D., K. D. Brunnemann and D. Hoffmann: Chemical studies on tobacco smoke, LXXV. Rapid method for the analysis of tobacco-specific $N$-nitrosamines by gas-liquid chromatography with a thermal energy analyser; J. Chromatogr. 256 (1983) 347-351.

10. Hecht, S. S., C. B. Chen, N. Hirota, R. M. Ornaf, T. C. T'so and D. Hoffmann: Tobacco-specific nitrosamines - Formation from nicotine in vitro and during tobacco curing and carcinogenicity in strain A mice; J. Natl. Cancer Inst. 60 (1978) 819-824.

11. Andersen, R. A., M. J. Kasperbauer, H. R. Burton, J. L. Hamilton and E. E. Yoder: Changes in chemical composition of homogenized leaf-cured and air-cured Burley tobacco stored in controlled environments; J. Agric. Food Chem. 30 (1982) 663668.

12. Andersen, R. A., and M. J. Kasperbauer: Post-harvest treatment and the accumulation of nitrite and $N$ 'nitrosonornicotine in Burley tobacco; in: $N$ nitroso compounds - Occurrence, biological effects and relevance to human cancer, edited by $I$. K. O'Neill; R. C. von Borstel, C. T. Miller, J. Long and $H$. Bartsch, International Agency for Research on Cancer, Lyon, IARC Sci. Publ. No. 57, 1984, pp. 877-883.

13. Hecht, S. S., C. B. Chen, R. M. Ornaf, D. Hoffmann and T. C. Tso: Chemical studies on tobacco smoke, LVI. Tobacco-specific nitrosamines Origins, carcinogenicity and metabolism; in: Envin ronmental aspects of $N$-nitroso compounds, edited by E. A. Walker, M. Castegnaro, L. Griciute and R. E. Lyle; International Agency for Research on Cancer, Lyon, IARC Sci. Publ. No. 19, 1978, pp. 395-413.

\section{Addresses of akt bors:}

S. V. Bhide,
Carcinogenesis Division,
Cancer Research Institute,
Tata Memorial Centre,
Bombay (Parel), 400012, India.

\section{B. V. Kameshwar Rao, Department of Biochemistry, Central Tobacco Research Institute, Rajabmundry, 53310S, India.}
M. K. Chakraborty,
Department of Biochemistry (Tobacco Project), Gujarat Agricultural University, Anand, 388110, India.

\author{
K. D. Brunnemann, \\ Naylor Dana Institute for Disease Prevention, \\ American Health Foundation, \\ Dana Road, \\ Valhalla, N.Y., 10595, U.S.A.
}

